\title{
THE POPULATION DENSITIES OF TWO MAJOR INSECT PESTS OF ONION; THE ONION THRIPS (Thrips tabaci Lindeman ) IN FIELDS AND THE ONION BULB FLY ( Eumerus amoenus Loew.) IN STORES
}

(Received: 1.4.2008)

\author{
By \\ S.I. El-Sherif and H.H. Mahmoud*

\begin{abstract}
Department of Economic Entomology and Pesticides, Faculty of Agriculture, Cairo University, Giza, Egypt and * Plant Protection Research Institute, Agriculture Research Center, Ministry of Agriculture, Giza, Egypt
\end{abstract}

\begin{abstract}
Onion plantations and stored onion bulbs are subjected to infestation with a variety of insect pests that considerably affect crop quality and quantity. Among these pests dominate the onion thrips Thrips tabaci (Thysanoptera: Thripidae) in the field and the onion bulb fly Eumerus amoenus (Diptera: Syrphidae) on stored bulbs. Population density of T. tabaci in onion fields studied throughout 3 successive growing seasons (2002/2003-2004/2005) at Assiut Governorate indicated that the pest's larvae and adults prevailed from early January until late May with 2 to 3 overlapping broods. The $1^{\text {st }}$ brood elapsed about 3 months extending from early January to early April, the $2^{\text {nd }}$ brood covered a period of about 2 months from early March until mid-April and the $3^{\text {rd }}$ brood lasted for about 2.5 months from mid- March until the end of May. Both the $1^{\text {st }}$ and the $3^{\text {rd }}$ broods were of definite annual occurrence while the $2^{\text {nd }}$ brood might or might not occur. The follow up of the population density of E. amoenus in onion stores throughout 3 successive storage seasons (2003-2005) revealed its frequent occurrence throughout the whole storage period which extended from June until November. The mean percentage of onion bulbs infested with $E$. amoenus was generally low (2.6\%) in June, moderate (7.3\%) in July, relatively high $12.2 \%$ in August and September $10.9 \%$ then moderate again $(7.3 \%)$ in October and low $(4.0 \%$.) in November. The pest underwent 4 successive overlapping generations throughout the storage period and the generation duration ranged from 7 to 9 weeks. The $1^{\text {st }}$ to the $4^{\text {th }}$ generations peaked by late July, the $2^{\text {nd }}$ half of August, the $2^{\text {nd }}$ half of September and throughout October. The $1^{\text {st }}$ generation was relatively weak while the $2^{\text {nd }}$ and $3^{\text {rd }}$ generations were quite strong and the $4^{\text {th }}$ generation was the weakest.
\end{abstract}

Key words: Eumerus amoenus, onion fields and stores, population densities, Thrips tabaci.

\section{INTRODUCTION}

In Egypt, onion (Allium cepa L.) is an important field crop for both local consumption and exportation. Onion plantations and stored onion bulbs are oftenly subjected to infestation with a variety of insect pests that considerably affect crop quality and quantity (Mahmoud, 2008). Onion plantations usually suffer insect attacks throughout their different growth stages from immediately after transplanting in December until harvest-time by May. During this period onion thrips Thrips tabaci (Thysanoptera: Thripidae) dominates as the most destructive threat. In onion stores, the dominant insect pest on stored onion bulbs throughout the storage season- which extends from May until November- is the onion bulb fly Eumerus amoenus (Diptera: Syrphidae).
Previous investigations on the population density of T. tabaci in onion plantations in Egypt include the works of Karaman (1970), Khalil et al. (1971), Haydar and Sherif (1987) and ElGendi (1998). Relevant investigations abroad include the studies of El-Serwiy et al.(1985) in Iraq, Edelson et al. (1986) in USA, Lu and Lee (1987) in Taiwan and Kalafchi et al. (2006) in Iran. As for the population density of E. amoenus throughout the storage period in Egypt, reference is made to the studies of El-Sherif (1971), Mikhael (1978), Abd-El-Fattah (1980), Ismail et al. (1990) and Massry (2002). Literature on the population density of the species E. amoenus abroad is, apparently, very scanty.

Mahmoud (2008) reported that in Egypt, the most economically important insect pests in onion 
fields and stores are T. tabaci and E. amoenus, respectively. Therefore, the present work investigated the population densities of these pests at Assiut Governorate which is considered one of the country's biggest onion production areas. It is hoped that such contribution might help establishing feasible recommendations for the management of the two considered pests.

\section{MATERIALS AND METHODS}

The study of the population density of Thrips tabaci was carried out in selected farmer fields planted with the commonly grown onion cultivar "Giza 6 Mohassan" at Assiut Governorate during the three successive onion growing seasons of 2002/2003 - 2004/2005. For each season, an area of $336 \mathrm{~m}^{2}$ was divided into four plots (replicates), each measuring 7 x 12 m. $\left(\begin{array}{llll}8 & \mathrm{~m}^{2}\end{array}\right)$ and transplanted with healthy onion seedlings by late November or early December. A random sample of 10 plants was taken from each replicate at quarter-monthly intervals, thus making a total sample size of 40 plants from the whole experimental field. Plant samples were taken between 3 p.m. and 5 p.m. from the beginning of January until the end of May. All plots were left to grow normally and no control measures were applied until harvest-time. Sampled plants were introduced into clean cloth bags, then transferred seasons of 2003-2005 in a store located at Assiut Governorate and full of stored bulbs of onion cultivar "Giza 6 Mohassan". In each considered storage season, a random quantity of $400 \mathrm{Kg}$. of stored onion bulbs was kept into four separate heaps each weighing $100 \mathrm{Kg}$. and regarded as a replicate. The heaps were separated from each other by $2 \mathrm{~m}$. distance and sampling from them was practiced at quarter-monthly intervals from the beginning of June until the beginning of November. At each date, a random sample of 25 bulbs was taken from each heap (replicate), thus the total size of the quarter-monthly sample was 100 bulbs. Sampled bulbs were carefully examined for infestation with E. amoenus and its existing larvae and / or pupae were counted.

\section{RESULTS AND DISCUSSION}

\subsection{The onion thrips, $T$. tabaci}

The quarter-monthly population densities of thrips individuals (larvae and adults) in onion fields at Assiut Governorate throughout the three successive onion growing seasons (2002/20032004/2005) are graphically illustrated in Fig.(1). In 2002/2003, thrips individuals began to occur in relatively small numbers (246/ 40 plants) during the $2^{\text {nd }}$ half of January and gradually increased in number throughout February and March until they reached a high peak of 2830/40 plants by mid

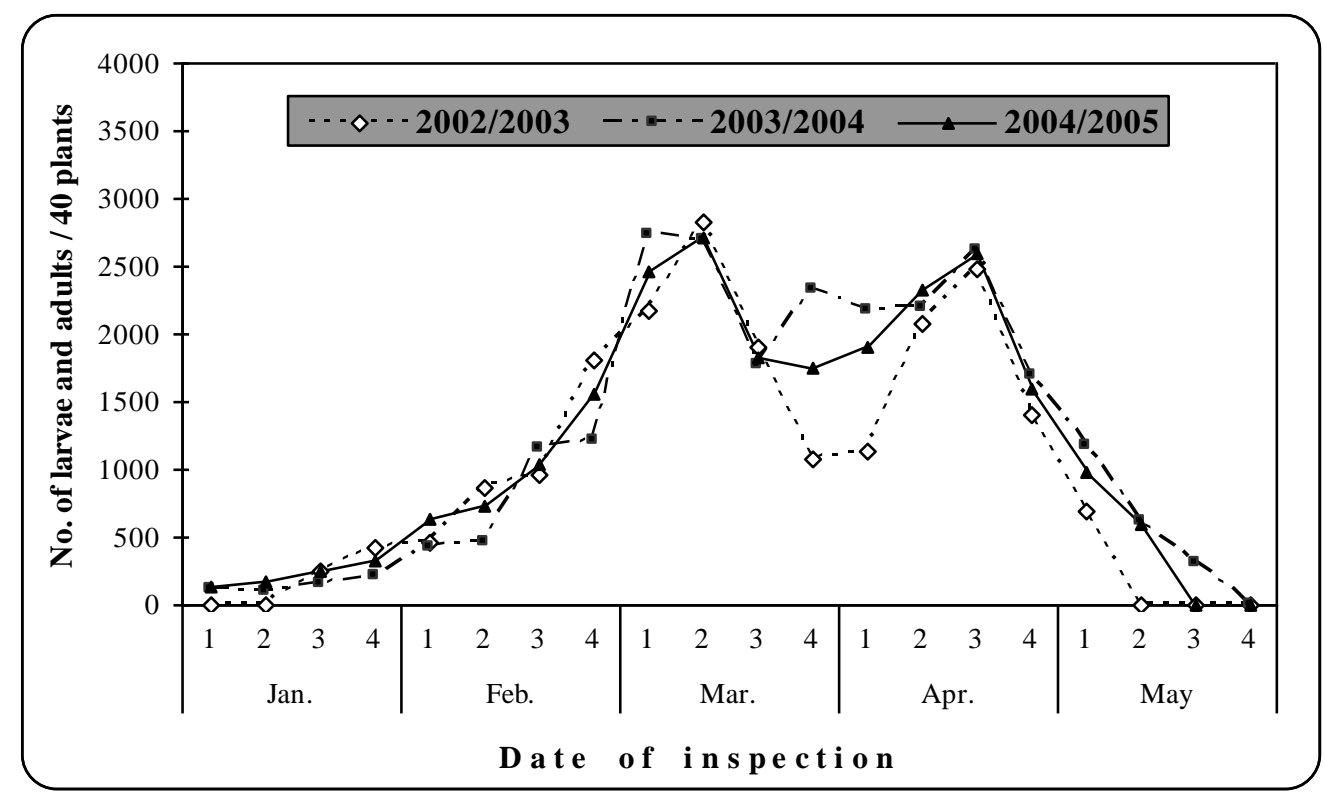

Fig. (1): Population densities of Thrips tabaci in onion fields at Assiut Governorate during three successive onion growing seasons $(2002 / 2003-2004 / 2005)$.

to the laboratory where they were examined for the occurrence and count of thrips larvae and / or adults.

The population density of E. amoenus was studied during the three successive storage
March. Thrips counts tended to decrease during the $2^{\text {nd }}$ half of March, then increased thereafter to reach another relatively high peak of 2485 individuals/ 40 plants. This second population peak was then followed by a noticeable decrease 
of thrips count to 684 individuals/40 plants by early May. No thrips individuals could be recorded in onion plantations starting from midMay. In 2003/2004, relatively small counts of thrips individuals occurred during January (103203/ 40 plants). Starting from early February, the population density tended to increase gradually but rather rapidly during the $2^{\text {nd }}$ half of the month. Population increase continued to a peak of 26862730 individuals/ 40 plants reached during the first half of March. This peak was followed by a drop in thrips count during the $3^{\text {rd }}$ quarter of March then a second peak of 2331 individuals/ 40 plants occurred by the end of the same month. Generally population density was relatively high during April (1698-2610 / 40 plants) and a third peak count took place during the $3^{\text {rd }}$ quarter of the month. The latter peak was followed by a gradual decrease of thrips population until onion plants became entirely free of infestation by the end of May. In 2004/ 2005, thrips individuals began to occur in relatively small counts by early January (138 /40 plants). Larval and adult counts increased gradually throughout January, February and March until a first peak of 2706 individuals / 40 plants took place by mid-March. Thrips counts were considerably high between mid-March and mid-April (1755-2332 individuals / 40 plants) then jumped to a second peak of 2598 individuals / 40 plants during the $3^{\text {rd }}$ quarter of April. This peak was followed by a gradual decline in thrips population until all larvae and adults completely disappeared from onion fields by mid-May.

Fig. (1) indicates that at Assiut Governorate, infestation with onion thrips prevails in onion fields from early January until mid- or late May. Throughout that prevalence period, 2-3 overlapping population broods of thrips are of possible occurrence. By integrating the population lines in the same figure it appears that the $1^{\text {st }}$ brood elapses about 3 months extending from early January to early April. The peak abundance of this particular brood mostly occurs by midMarch (67.7 - 70.8 individuals / plant). The $2^{\text {nd }}$ brood covers a period of about 2 months from early March until mid- April with a relatively smaller peak of 58.3 individuals / plant. The $3^{\text {rd }}$ brood lasts for about 2.5 months from mid-March until the end of May with a comparatively high peak of 62.1- 65.3 individuals / plant. Fig. (1) further indicates that both $1^{s t}$ and $3^{\text {rd }}$ broods are of definite annual occurrence while the $2^{\text {nd }}$ brood may or may not occur in certain years. As for the relative sizes of the different broods it seems that the $1^{\text {st }}$ and $3^{r d}$ broods are of nearly equal size while the $2^{\text {nd }}$ brood - whenever happens - is slightly smaller.

At Assiut Governorate, thrips counts in onion fields tended to increase from an onion growing season to the next. The total counts of thrips individuals for the whole season were 20548 in $2002 / 2003,22411$ in2003/2004 and 23608 in 2004/ 2005. Similarly, the respective mean numbers of thrips individuals / inspection were 1284.3, 1400.7 and 1475.5 for 2002/2003, $2003 / 2004$ and 2004/2005 seasons, respectively. Such counts emphasize the tendency towards population increase one season after another.

The above results more or less agree with the findings of a group of investigations conducted in Egypt. Karaman (1970) and Khalil et al. (1971) coincided that the various stages of T. tabaci are found in onion fields in relatively low numbers during December, then increase rapidly to reach maximum abundance throught April. Haydar and Sherif (1987) mentioned that the population of $T$. tabaci begins to build up by early February and reaches its maximum during April. El-Gendi (1998) stated that T. tabaci is active in onion fields from mid-December to mid-May. Furthermore, El-Serwiy et al. (1985) observed that in Iraq the population density of T. tabaci varies from one year to another and reaches a peak by early April. In Texas, USA, Edelson et al. (1986) found that $T$. tabaci individuals occur in onion fields from February till harvest-time in April or May with a peak of abundance in early April. $\mathrm{Lu}$ and Lee (1987) contributed that the population density of $T$. tabaci in Taiwan increases from November to April. Kalafchi et al. (2006) added that in Iran the population density of T. tabaci is the highest 130-158 days after planting.

\subsection{The onion bulb fly, $E$. amoenus}

The quarter-monthly rate of infestation with E. amoenus (represented as the number of infested bulbs per 100 bulbs i.e., percentage of infested bulbs) and its population fluctuations (represented as total larval and pupal counts per 40 bulbs) at Assiut Governorate during the three successive storage seasons of 2003-2005 are graphically illustrated in Fig. (2) and Fig. (3), respectively.

\subsubsection{The percentage of bulb infestation}




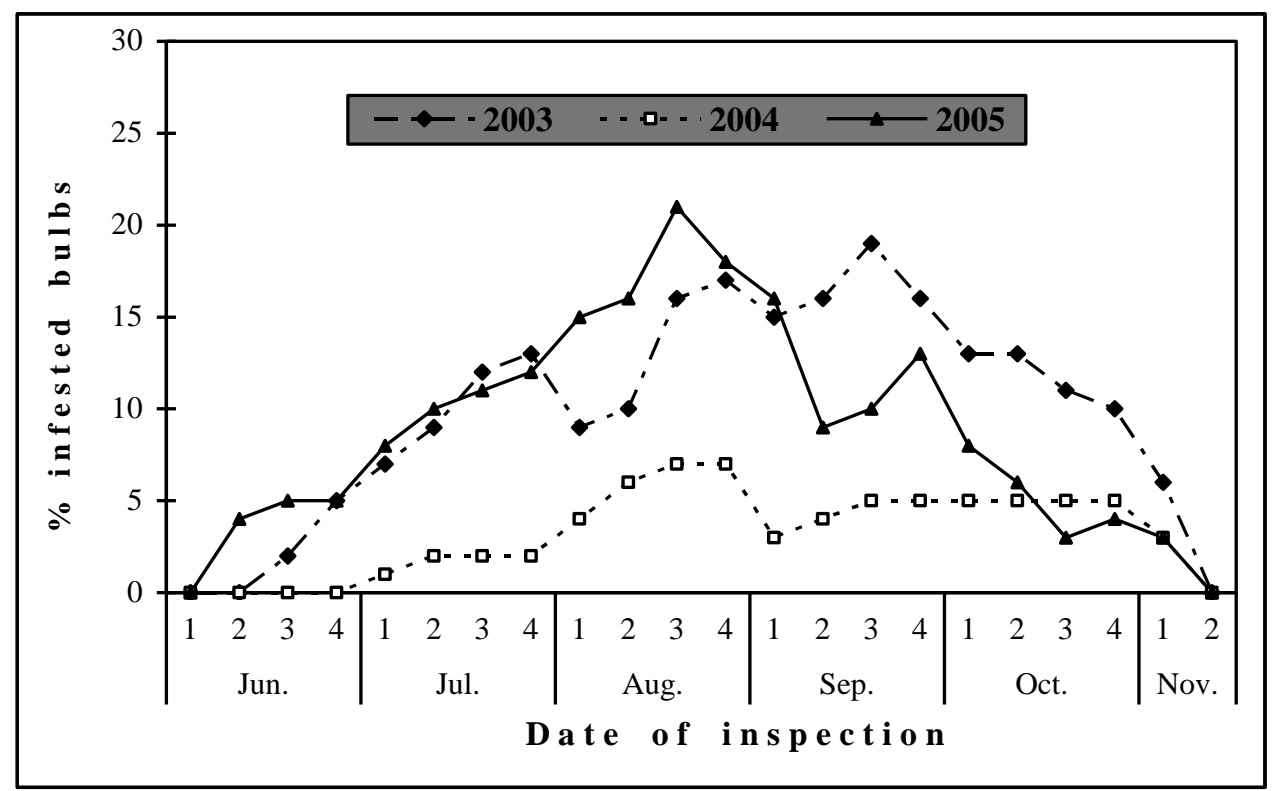

Fig. (2): Percentage of bulb infestation with E. amoenus on stored onion bulbs at Assiut Governorate during the storage seasons $2003-2005$.

Fig. (2) shows that the highest percentage of infested bulbs occurred in 2003 (2-19\%, with a mean of $11.5 \%$ ) and the lowest percentage took place in $2004(1-7 \%$, with a mean of $3.6 \%)$ while in 2005 this percentage was slightly less than in 2003 (3-21\%, with a mean of $9.9 \%$ ). For the three storage seasons collectively, the percentage of infested bulbs was generally low in
June $(0-5 \%$, with a mean of $2.6 \%)$, moderate in July (1-13\%, with a mean of $7.3 \%$ ), relatively high in August and September (4-21\%, with a mean of $12.2 \%$ and $3-19 \%$, with a mean of $10.9 \%$, respectively) then moderate again in October (3$13 \%$, with a mean of $7.3 \%$ ) and low in November (3-6\%, with a mean of $4.0 \%)$. The same figure further indicates that, based on the quarter-

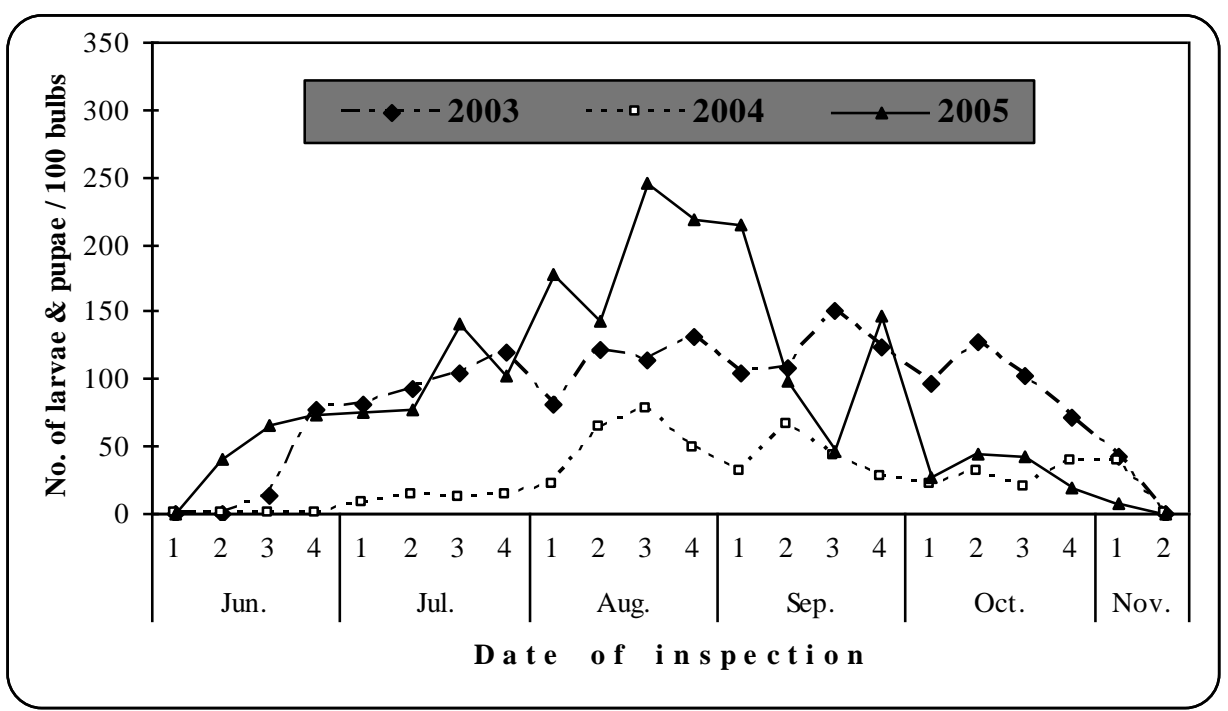

Fig. (3): Total number of $E$. amoenus larvae and pupae recorded on stored onion bulbs at Assiut Governorate during the storage seasons 2003 - 2005. 
monthly changes of the percentages of infested bulbs, E. amoenus had four population peaks throughout each storage season. These peaks could be roughly approximated as shown in Table (1) which refers that in 2003 - the season with the highest infestation - the four peaks were quite distinct whereas in both 2004 and 2005 the seasons with relatively less infestation, only three peaks could be recognized while the fourth one was too small. Such approximation for the peaks of infestation percentage on the stored onion bulbs leads to the general conclusion that, at Assuit Governorate, infestation with E. amoenus reaches peaks during the $4^{\text {th }}$ quarter of July, the $3^{\text {rd }}-4^{\text {th }}$ quarters of August, the $3^{\text {rd }}-4^{\text {th }}$ quarters of September and throughout October.

\subsubsection{Total larval and pupal populations}

Fig. (3). shows that in 2003, onion bulbs began to show infestation with $E$. amoenus larvae during the $2^{\text {nd }}$ half of June. Pupae were noticed in July and the total number of larvae and pupae reached a high $1^{\text {st }}$ peak of $120 / 100$ bulbs during the $4^{\text {th }}$ quarter of the same month. This peak was followed by a small decline in the total larval and pupal count then a $2^{\text {nd }}$ high peak of 122 larvae and pupae/100 bulbs occurred by mid-August. Total larval and pupal count remained noticeably high in August and September until a $3^{\text {rd }}$ relatively higher peak of $150 / 100$ bulbs took place during the $3^{\text {rd }}$ quarter of September. Larval and pupal count tended to decline between late September and early October but it regained increase towards a $4^{\text {th }}$ high peak of $128 / 100$
100 bulbs was observed by mid August. The $2^{\text {nd }}$ peak was followed by a gradual decline in larval and pupal count between late August and early September, then this count increased to a moderate $3^{\text {rd }}$ peak of 66/ 100 bulbs reached during the $2^{\text {nd }}$ quarter of September. Although larval and pupal count tended to oscillate thereafter, a $4^{\text {th }}$ relatively small peak of $31-39 / 100$ bulbs took place during the $2^{\text {nd }}$ half of October and by early November. In 2005, the larvae and pupae of $E$. amoenus were found on the stored onion bulbs starting from the $2^{\text {nd }}$ quarter of June and their total count increased rapidly towards a $1^{s t}$ high peak of $142 / 100$ bulbs recorded during the $3^{\text {rd }}$ quarter of July. Larval and pupal count was noticeably high between mid-July and mid-August and reached a markedly high $2^{\text {nd }}$ peak of $245 / 100$ bulbs during the $3^{\text {rd }}$ quarter of August. The latter peak was followed by a continuous decrease of total larval and pupal count until the $3^{\text {rd }}$ quarter of September when it increased again towards a $3^{\text {rd }}$ high peak of 147 / 100 bulbs reached during the $4^{\text {th }}$ quarter of the same month. A $4^{\text {th }}$ relatively smaller peak of 44 larvae and pupae/ 100 bulbs took place about two weeks later during the $2^{\text {nd }}$ week of October. Larvae and pupae tended to decrease in number gradually thereafter until they completely disappeard by the end of the storage season about mid-November.

Data in Figs. (2\&3) seem to more or less agree with the findings of the previous investigators. ElSherif (1971) who observed that stored onion bulbs are liable to infestation with E. amoenus

Table (1): Approximate periods of peak occurrence of $E$. amoenus on stored onion bulbs throughout the storage period for $2003-2005$ seasons.

\begin{tabular}{|c|c|c|c|}
\hline \multirow{2}{*}{ Peak } & \multicolumn{3}{|c|}{ STORAGE SEA SON } \\
\hline & 2003 & 2004 & 2005 \\
\hline First & $\begin{array}{l}4^{\text {th }} \text { quarter } \\
\text { of July }\end{array}$ & $*$ & $\begin{array}{l}4^{\text {th }} \text { quarter } \\
\text { of July }\end{array}$ \\
\hline Second & $\begin{array}{l}4^{\text {th }} \text { quarter } \\
\text { of August }\end{array}$ & $\begin{array}{l}3^{\text {rd }} \& 4^{\text {th }} \text { quarters } \\
\text { of August }\end{array}$ & $\begin{array}{l}3^{r d} \text { quarter } \\
\text { of August }\end{array}$ \\
\hline Third & $\begin{array}{l}3^{r d} \text { quarter } \\
\text { of September }\end{array}$ & $\begin{array}{l}3^{r d} \& 4^{\text {th }} \text { quarters } \\
\text { of September }\end{array}$ & $\begin{array}{l}4^{\text {th }} \text { quarter } \\
\text { of September }\end{array}$ \\
\hline Fourth & $\begin{array}{l}1^{s t} \& 2^{\text {nd }} \text { quarters } \\
\text { of October }\end{array}$ & $\begin{array}{l}1^{s t}-4^{\text {th }} \text { quarters } \\
\text { of October }\end{array}$ & $*$ \\
\hline
\end{tabular}

bulbs during the $2^{\text {nd }}$ quarter of the latter month. In 2004, no larval or pupal infestations were recorded during June. Larvae began to occur on stored bulbs throughout July with a $1^{\text {st }}$ small peak of 13 larvae / 100 bulbs by the end of the month. A $2^{\text {nd }}$ moderate peak of 77 larvae and pupae / maggots from mid-June until early November. Mikhael (1978) mentioned that the percentage of E. amoenus infestation to stored onion bulbs reaches a peak by the beginning of the $2^{\text {nd }}$ week of July. Abd-El-Fattah (1980) added that the highest mean percentage of infestation with $E$. amoenus 
on onion bulbs (12.5\%) occurs in July and the highest level of larval and pupal populations on them (a mean of $40.5 / \mathrm{bulb}$ ) takes place in August. Ismail et al. (1990) reported that the larvae of $E$. amoenus are first seen on stored onion bulbs during the $1^{\text {st }}$ week of June then they increase in number towards two peaks; one during the $1^{\text {st }}$ week of July and the other by mid-August. Massry (2002) contributed that the infestation of stored onion bulbs with E. amoenus reaches a maximum by late July or early August.
September and mid-November. As for the relative sizes of the above-mentioned four generations, a glance to Figs . (2\&3) reveals that the $2^{\text {nd }}$ and $3^{\text {rd }}$ generations are relatively stronger than the $1^{s t}$ and $4^{\text {th }}$ generations. Based on the quarter -monthly percentages of bulb infestation during the two storage seasons with the comparatively high infestation with E. amoenus (2003 and 2005, Fig.2) as well as the quarter-monthly total larval and pupal counts during the same two storage seasons (Fig.3), it seems that the $1^{\text {st }}$ generation is

Table (2): Approximate occurrence periods of the four successive overlapping generations of E. amoenus on stored onion bulbs throughout the storage period for 2003-2005 seasons.

\begin{tabular}{|c|c|c|c|}
\hline \multirow{2}{*}{ GENERATION } & \multicolumn{3}{|c|}{ 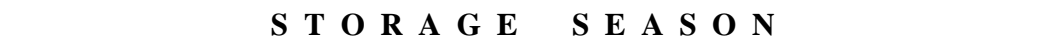 } \\
\hline & 2003 & 2004 & 2005 \\
\hline $\begin{array}{cc}\text { FIRST : } & \\
& \text { From } \\
& \text { To }\end{array}$ & $\begin{array}{l}2^{\text {nd }} \text { quarter } \\
\text { of June } \\
2^{\text {nd }} \text { quarter } \\
\text { of August } *(9)\end{array}$ & $\begin{array}{l}4^{\text {th }} \text { quarter } \\
\text { of June } \\
2^{\text {nd }} \text { quarter } \\
\text { of August } *(7)\end{array}$ & $\begin{array}{l}\mathbf{1}^{\text {st }} \text { quarter } \\
\text { of June } \\
\mathbf{1}^{\text {st }} \text { quarter } \\
\text { of August } *(9)\end{array}$ \\
\hline $\begin{array}{c}\text { SECOND : } \\
\text { From } \\
\text { To }\end{array}$ & $\begin{array}{l}3^{r d} \text { quarter } \\
\text { of July } \\
3^{\text {fd }} \text { quarter of September } \\
*(9) \\
(9)\end{array}$ & $\begin{array}{l}4^{\text {th }} \text { quarter } \\
\text { of July } \\
2^{\text {nd }} \text { quarter of } \\
\text { September *(7) }\end{array}$ & $\begin{array}{l}2^{\text {nd }} \text { quarter } \\
\text { of July } \\
1^{\text {st }} \text { quarter of } \\
\text { September } *(8)\end{array}$ \\
\hline $\begin{array}{c}\text { THIRD : } \\
\text { From } \\
\text { To }\end{array}$ & $\begin{array}{l}4^{\text {th }} \text { quarter } \\
\text { of August } \\
3^{r d} \text { quarter of October } \\
*(8)\end{array}$ & $\begin{array}{l}3^{r d} \text { quarter } \\
\text { of August } \\
2^{n d} \text { quarter of } \\
\text { October } \quad *(8)\end{array}$ & $\begin{array}{l}1^{s t} \text { quarter } \\
\text { of August } \\
4^{\text {th }} \text { quarter of } \\
\text { September } *(9)\end{array}$ \\
\hline $\begin{array}{r}\text { FOURTH : } \\
\text { From } \\
\text { To }\end{array}$ & $\begin{array}{l}2^{n d} \text { quarter } \\
\text { of September } \\
2^{n d} \text { quarter of November } \\
*(9)\end{array}$ & $\begin{array}{l}3^{r d} \text { quarter } \\
\text { of September } \\
2^{n d} \text { quarter of } \\
\text { November } *(8)\end{array}$ & $\begin{array}{l}2^{\text {nd }} \text { quarter } \\
\text { of September } \\
2^{\text {nd }} \text { quarter of November } \\
*(9)\end{array}$ \\
\hline
\end{tabular}

* Figures between brackets represent the approximate generation durations in weeks

\subsubsection{Number of generations throughout storage period}

By integrating the lines representing the quarter - monthly fluctuations of larval and pupal counts of E. amoenus in onion stores for the three successive storage seasons (Fig. 3), it appears that the pest undergoes four overlapping generations throughout the storage period which extends from early June until early November. An approximation of the occurrence periods of these generations and the duration of each generation is presented in Table (2). This table indicates that the $1^{s t}$ generation takes place from early June to midAugust and lasts for about 7-9 weeks. The $2^{\text {nd }}$ generation elapses the period between mid-July and mid-September and lasts for about 7-9 weeks also. The $3^{\text {rd }}$ generation covers a period of about 8-9 weeks between early August and midOctober. The duration of the $4^{\text {th }}$ generation ranges about 8-9 weeks extending between mid- relatively weak while the $2^{\text {nd }}$ and $3^{\text {rd }}$ generations are quite strong and the $4^{\text {th }}$ generation is the weakest.

\section{REFERENCES}

Abd-El-Fattah T. A. (1980). Factors affecting the insect population during the storage of onion bulbs. M.Sc. Thesis, Fac. Agric., Al-Azher Univ., Egypt, 94 pp.

Edelson J.V., Cartwright B. and Royer T. A. (1986). Distribution and impact of Thrips tabaci (Thysanoptera : Thripidae) on onion. J. Econ. Entomol., 79 (1): 502-505.

El-Gendi S. M. (1998). Population fluctuation of Thrips tabaci Lind. on onion plants under Fayoum environmental conditions. Arab Universities J. Agric. Sci., 6 (1): 267-276.

El-Serwiy S. A., Razoki I. A. and Ragab A.S. (1985). Population density of Thrips tabaci Lind. and the predators Orius albidipennis 
Reut. and Aeolothrips fasciatus L. on onion. J. Agric. Water Reso. Res., 4 (3): 57-67.

El-Sherif A. R. A. (1971). Studies on insects infesting onion and garlic in field and storage. Ph. D. Thesis, Fac. Agric., Cairo Univ., Egypt, 279 pp.

Haydar M. F. and Sherif, L. S. (1987). Ecological aspects and developing method of onion pest control. Bull. Soc. Ent. Egypt, Economic Series, 16: 119-126.

Ismail, I. I.; El-Bolok, M. M. and El-Shabrawy, H. A. (1990). Population fluctuations of two onion bulb flies (Eumerus amoenus Loew. and E. vestitus Bez., Syrphidae, Diptera) and their parasites in the store. Bull. Soc. Ent. Egypt 69: 89-96.

Kalafchi M., Mobli M., Ebadi R. and Rezaei A. M. (2006). A study of population fluctuations of onion thrips (Thrips tabaci Lind.) and its effect on bulbing and yield of selected onion cultivars in Isfahan. Iranian Journal of Agricultural Sciences, 36 (6): 465-477.
Karaman G. A. I. (1970). Studies on certain pests of onion with special reference to their control. M. Sc. Thesis, Fac. Agric., Assiut Univ., Egypt, 170 pp.

Khalil, F. M.; El-Sebae, A. H. and Karaman, G. A. (1971). Some ecological studies on Thrips tabaci Lind. Assiut J. Agric. Sci., 2 (1): 197-206.

Lu F. M. and Lee H. S. (1987). The life history and seasonal occurrence of onion thrips (Thrips tabaci Lindeman). Journal of Agricultural Research of China, 36 (1): 118-124.

Mahmoud H.H.(2008). Ecological studies on certain insect pests of onion with special emphasis on the onion bulb fly Eumerus amoenus Loew. (Diptera : Syrphidae). Ph. D. Thesis, Fac. Agric., Cairo Univ., Egypt, 125 pp.

Massry S. H. D. (2002). Ecological and bio-control studies on some pests infesting onion and garlic crops. M. Sc. Thesis, Fac. Agric., Menoufia Univ., Egypt, 162 pp.

Mikheal R. H. G. (1978). Biological studies on certain onion flies and their control. M. Sc. Thesis, Fac. Agric., Ain Shams Univ., Egypt, 95 pp.

$$
\begin{aligned}
& \text { كثافات التعداد لأفتين حشريتين هامتين على البصل: }
\end{aligned}
$$

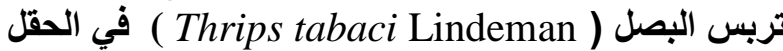

$$
\begin{aligned}
& \text { وذبابة البصل الكبيرة (. Eumerus amoenus Loew) في المخزن (Eum فئن } \\
& \text { سمير الثريف إبر اهيم الثريف ـ حمدي حسين محمود* }
\end{aligned}
$$

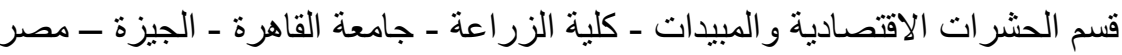

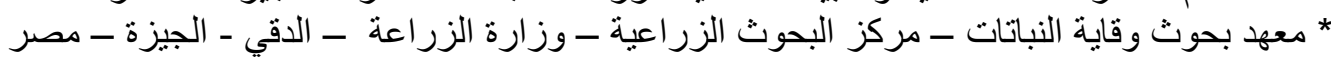

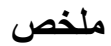

تتعرض زر اعات البصل وكذلك الأبصال المخزنة للإصابة بعديد من الآفات الحشرية التي تؤثر بشكل كبير على إنى

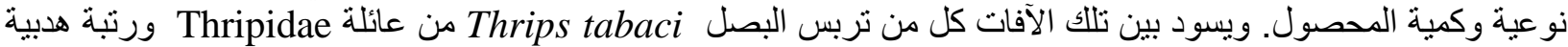

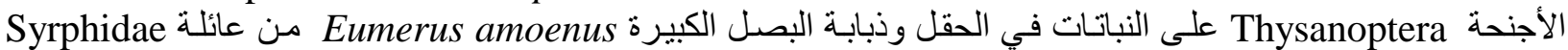

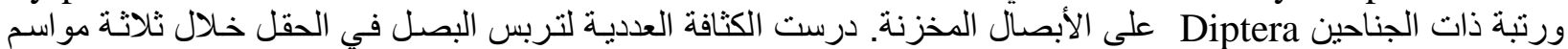

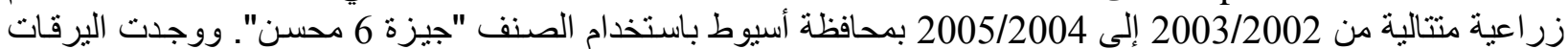

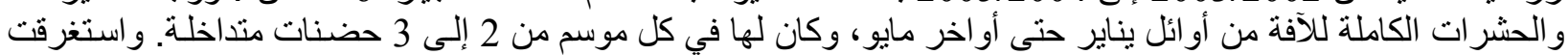

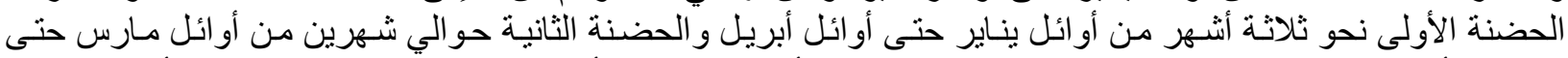

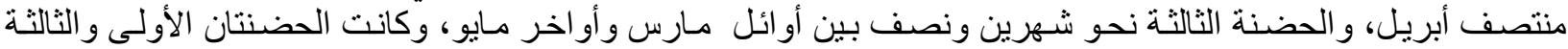

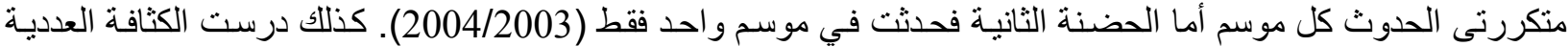
ليرقات و عذارى ذبابة البصل الكبيرة خلال ثلاثة مو اسم تخزينية متتالية (2003 - 2005) بمحافظة أسيوط باستخدام الصنف

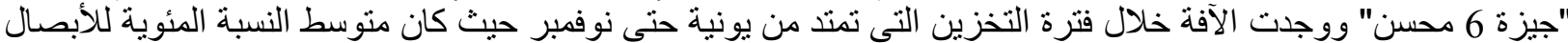

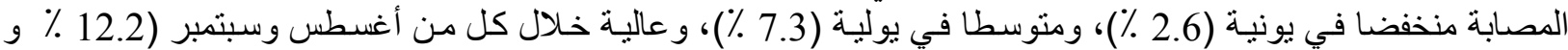

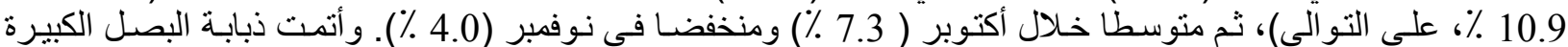

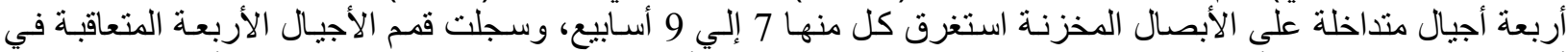

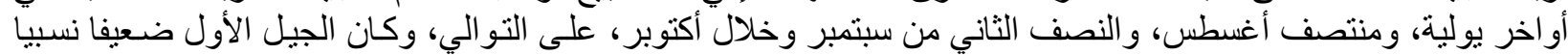
أما الجيلان الثاني و الثالث فكانا قويان في حين كان الجيل الر ابع الثيع أضعف الأجيال.

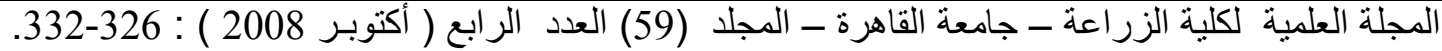

